\title{
Furniture Online Shopping using Augmented Reality
}

\author{
B Kurniawan ${ }^{1}$, E P Fadryan ${ }^{2}$ \\ \{bobi@unikom.ac.id ${ }^{1}$, $\underline{\text { erzypf@email.unikom.ac.id }}^{2}$ \} \\ Department of Electrical Engineering, Universitas Komputer Indonesia, Indonesia ${ }^{1}$, \\ Department of Management, Universitas Komputer Indonesia, Indonesia ${ }^{2}$
}

\begin{abstract}
The purpose of this study was to determine the level of effectiveness in buying furniture products online using Augmented Reality. The methods used for this research is a descriptive method which is done by conducting interviews with consumers and making analysis. The results obtained based on research methods used are that the use of Augmented Reality is more effective because the product which is to be purchased can be tried virtually, making it easier for consumers to try a product without coming directly to the shop. So, with the utilization of the technology of Augmented Reality, it can make it easy for every consumer to know and try every product details which are offered by the furniture store.
\end{abstract}

Keywords: Online Shopping, Augmented Reality, Furniture Store.

\section{Introduction}

Information technology today brings many changes and makes all things easier. One of them is the online business process in an organization or company which is used to market their products globally more quickly and dynamically [1]. With the help of revolutionary technology today, and to be more interactive with consumers, selling product by online is not presented in the form of two-dimensional images but rather in three dimensions. For that, we need an application model called AR (Augmented Reality). Augmented Reality is the latest technology for real-based reality, from laboratories, industries, unto entering the world of trading business [2]. Using AR can help consumers in making decisions to buy a product [3] as well as helping a company to benefit from its competitors [4].

Operating an AR effectively can help companies promote their products because consumers can interact directly with the product [5]. So AR allows consumers to see objects in three dimensions like in the real world [6]. However, AR is still an experiment in marketing a product and is usually only used as a promotional tool that can get positive results from consumers [7]. Even so, AR has an appeal for consumers to test the products and can allure them to buy it [8]. With this, consumers are more able to choose products in an interactive way so that businesses can create a positive relationship between a product brand and their consumers [9]. In addition, it can assists consumers in choosing products because AR can direct their devices to a product catalog and display a complete description of the product [10].

Previous research focuses more on the functions of augmented reality as a promotional and media as a means of introducing the products $[1,2,3]$, then on research utilization AR which is used for media promotion, the real form of imitation products, as well as helping consumers in order to be able to just shop online. So consumers are satisfied with online shopping when utilizing the technology of augmented reality.

If previous research focuses more on the functions of augmented reality as a promotional and media as a means of introducing the products $[1,2,3]$, rather than on research utilization AR used for media promotion, the real form of imitation products, as well as helping consumers in 
order to be able to just shop online. Therefore, consumers are satisfied with online shopping when utilizing the technology of augmented reality.

\section{Material and Methods}

This research used a descriptive approach method. Descriptive method has several steps, namely to formulate the problem, determine goals, formulate the framework, looking for literature, and others. This research focuses on two stages, namely to formulate problems and literature using data collection techniques in the form of an interview directly against the data source. This research focuses on the consumer data retrieval application using IKEA by adding feature Augmented Reality. Data is the data against the satisfaction of application usage IKEA added with the additional features of the AR to assist the consumer in selecting the furniture that you want. After that, the level of effectiveness against the consumer satisfaction in using the application is calculated.

\section{Results and Discussion}

After interviewing customers, 8 out of 10 consumers thought that using this application is very effective for buying furniture products at IKEA because this application can make virtual products in the form of a scale that is really the same as the original scale of the product so that consumers can try it first. Also, the resulting virtual image is very clear and accurate.

To make it easier for consumers using the application, IKEA makes the appearance of this application in a concise and user-friendly view, with the usage instructions on each feature. When opening this application, the consumer will be presented with the IKEA splash screen display (Figure 1).

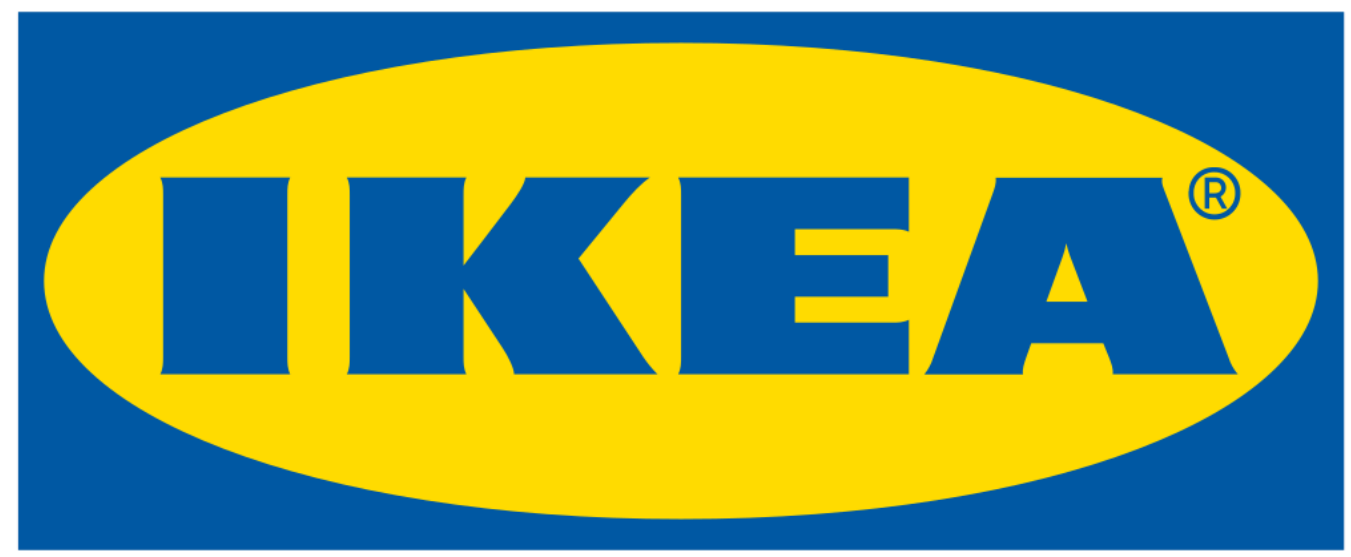

Fig 1. Splash screen.

The figure was adapted from ikea.co.id/ July 15th, 2018.

Figure 1 shows that there is a logo of the souvenir product that serve as the opening logo application. After the finished logo is displayed the user enters the main page of the application. On the main page there are several menu including scan, catalog, user object, and the Favorites menu. 
The scan menu is the menu that is used to perform a scan of the object product that you want to display on the application with based augmented reality. Catalogue menu is a menu that displays a description of some of the products in the store. After that, there is a User menu in which there is a list of favorite consumer items and a set menu for the consumer location is in Figure 2.

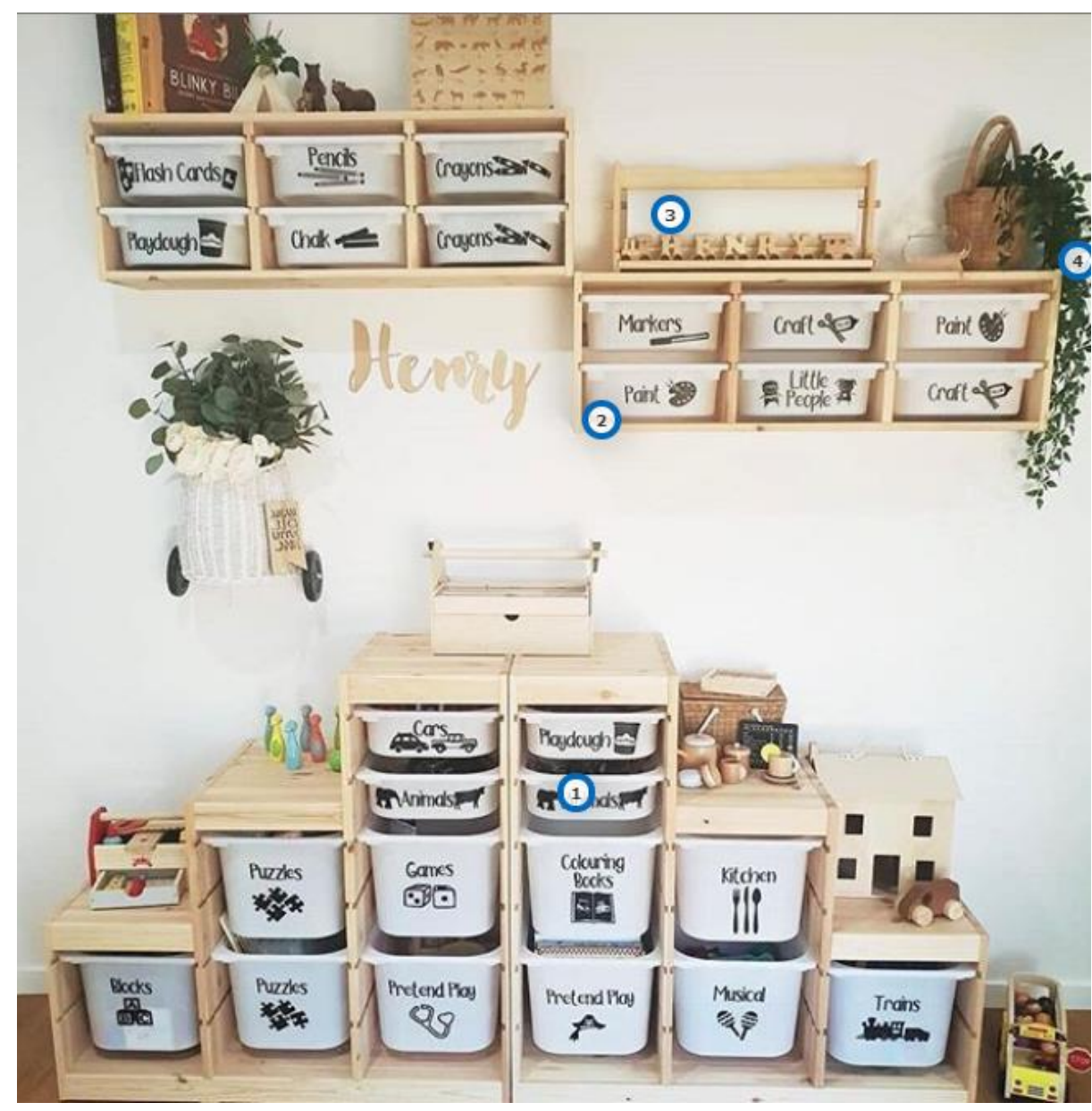

Fig 2. Main Menu.

Figure was adopted from ikea.co.id/ July 15th, 2018.

On the user interface on the Figure 2 there is consumer Favorites, list items, and the location of the menu for the consumer. This serves to give the desired furniture menu list by consumers. The menu for scanning is shown in Figure 3. 


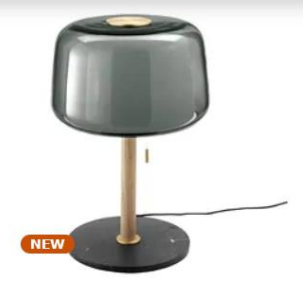

EVEDAL Table lamp $\$ 179$

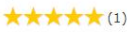

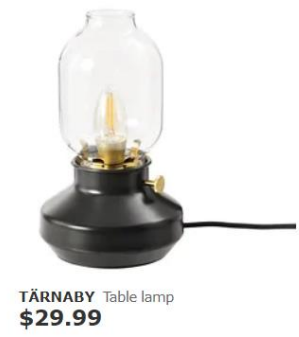

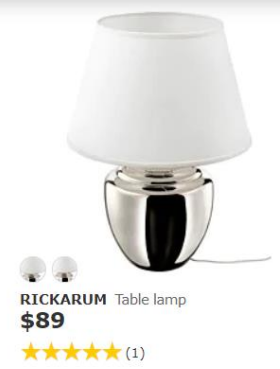

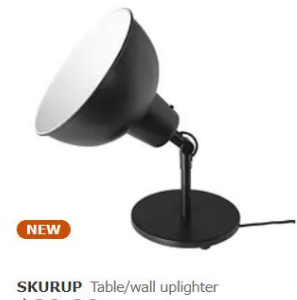
$\$ 29.99$
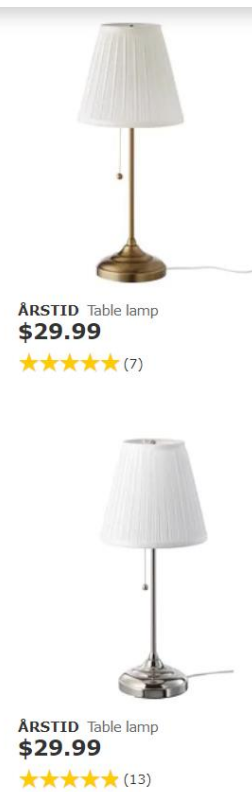
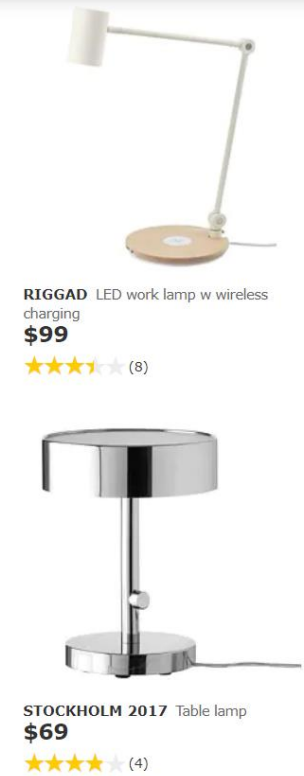

Fig 3. Scan Object.

Figure was adapted from ikea.co.id/ July 15th, 2018.

This menu allows consumers need to take photos contained at about the location of the consumer, and then the application will look for objects with similarities on objects that are in the photo with your existing catalog on application of IKEA. The catalog menu is shown in Figure 4.

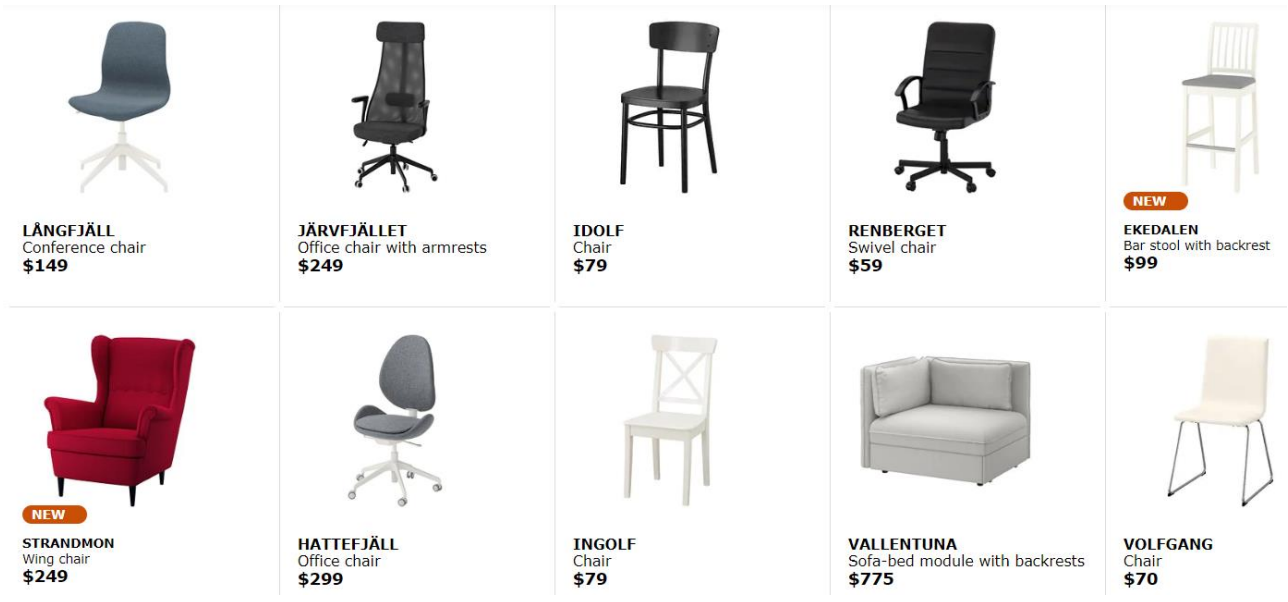

Fig 4. Catalog Menu.

The figure was adapted from ikea.co.id/ July 15th, 2018.

After the selection process the products seen on the menu catalogue, consumers can try on virtual products by selecting the button "try your place". With applications based on the technology of Augmented Reality, that will be the result of the selected products in tangible form such as native. After performing, the consumer can change the direction and position of the product as shown in Figure 5. 


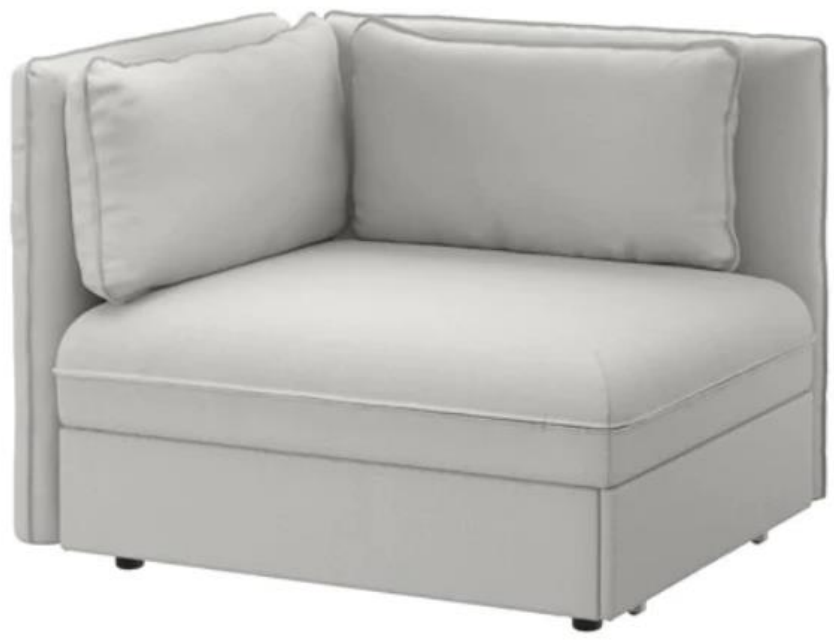

Fig 5. Try in Your Place.

Figure was adapted from ikea.co.id/ July 15th, 2018.

The last menu is the data storage of goods that have been selected by consumers. This makes it easy to collect the consumer data to see more products that have ever been seen or ever will be tested by consumers so that consumers no longer need to search for previous products that had been sought as indicated by Figure 6.

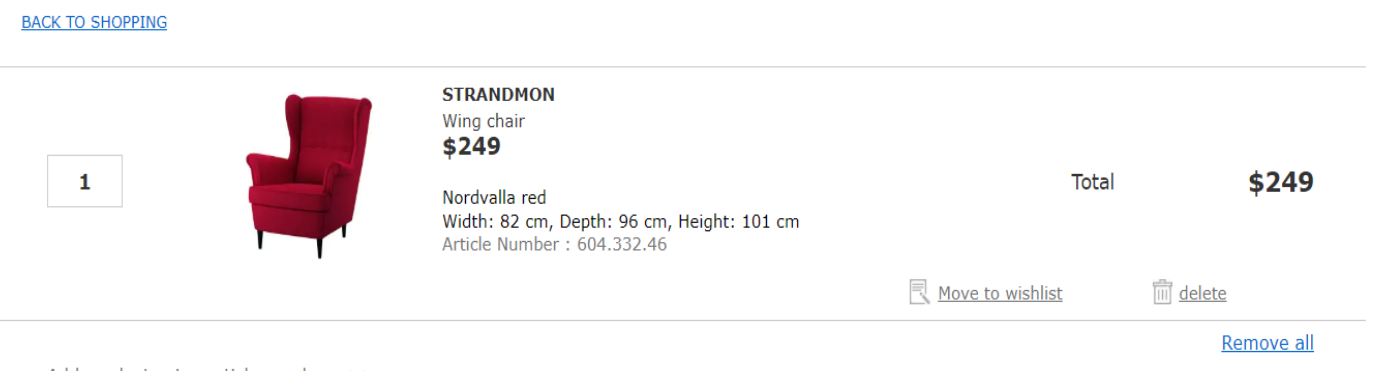

Fig 6. User.

Figure was adapted from ikea.co.id/ July 15th, 2018.

Utilization technology of Augmented Reality based application makes it easy for any user in trying any product which is used. This is in tune with the utilization of augmented reality that can add value to a product that is used [3].

\section{Conclusion}

The development of technology today can make things easy, especially for the business world of buying and selling. With the augmented reality feature, it is very helpful for consumers who want to buy or just look at a product without having to go to the retailer's shop. 


\section{References}

[1] Soegoto, E. S.: Entrepreneurship Menjadi Pebisnis Ulung. Elex Media Komputindo. (2013).

[2] Krevelen, V. D.: A Survey of Augmented Reality Technologies, Applications and Limitations. The International Journal of Virtual Reality, pp. 1-20. (2010).

[3] Nayyar A., Mahapatra N., DacNhuong L., Suseendran G.: Virtual Reality (VR) \& Augmented Reality (AR) Technologies for Tourism and Hospitality Industry. (2018).

[4] Elham Baratali, M. H.: Effective Of Augmented Reality (AR) In Marketing Communication: A Case Study On Brand Interactive Advertising. (2016).

[5] Azuma, R.: In Presence: Teleoperators and Virtual Environments. A Survey of Augmented Reality, pp. 355-385. (1997).

[6] Haller M., Bilinghurst M., Thomas B.: Emerging Technologies of Augmented Reality: Interfaces and Design. (2007).

[7] Bulearca M., Tamarjan D.: Augmented Reality: A Sustainable Marketing Tool? Global Business and Management Research: An International Journal, pp. 237-252. (2010).

[8] Owyang, J.: The New Reality Will Be Augmented. Customer Retalionship Management, pp. 32-33. (2010).

[9] Eyüboğlu, E.: Augmented Reality As An Exciting Online Experience: Is It Really Beneficial For Brands?, pp. 115-116. (2011).

[10] Agrawal M., Kulkami A., Joshi S., Tiku N.: Augmented Reality., pp. 120-121. (2015).

[11] Punaji, S.: Metode Penelitian Pendidikan dan Pengembangan. Jakarta: Kencana. (2010). 